\title{
GHANA'S 2016 GENERAL ELECTION: Accounting for the Monumental Defeat of the National Democratic Congress (NDC)
}

\section{Ransford Edward Van Gyampo, Emmanuel Graham and Eric Yobo}

Ransford Edward Van Gyampo is an Associate Professor in the Political Science Department, University of Ghana and also serves as a Senior Research Fellow at the Governance Unit of the Institute of Economic Affairs, Ghana email:vangyampo@yahoo.com

Emmanuel Graham is a graduate assistant at the Department of Political Science, University of Windsor, Ontario, Canada email: kofigraham@gmail.com

Eric Yobo is a PhD candidate at the Ghana Institute of Management and Public Administration (GIMPA), School of Public Service and Governance, Ghana email: ericyobo85@gmail.com

\begin{abstract}
Ghana is now seen as a thriving African democracy after having gone through seven presidential and parliamentary elections, resulting in three overturns of political power in 2001, 2009 and 2017. The 2016 election was another crossroad for Ghana's maturing democracy. In this election, the incumbent National Democratic Congress (NDC) lost to the opposition New Patriotic Party (NPP). The margin of defeat suffered by the ruling NDC was puzzling and unprecedented. Using voter behaviour as a theoretical taxonomy, this paper attempts to explain the monumental defeat of the NDC in the 2016 general election. It poses the question: what factors led to this defeat and why was there such a monumental difference of over one million votes? The paper argues that firstly, the defeat was due to regime fatigue anchored in the two-term regime cycle of change and voting based on party identification. Secondly, the defeat was monumental because of poor economic performance: corruption on the part of some government ministers and attempts to shield them; unpopular last minute decisions; the gross display of arrogance by some ministers of state and party officials; a more appealing campaign message of hope from the main opposition party; poor branding and communication of NDC's campaign promises and ideas; abuse of incumbency; voter apathy
\end{abstract}


on the part of ruling party supporters and the general call for change across the world. The study concludes by offering some useful recommendations.

Keywords: Ghana, National Democratic Congress (NDC), New Patriotic Party (NPP), defeat, democracy, elections, democratic consolidation

\section{INTRODUCTION}

Since Ghana's fourth attempt at constitutional democracy in 1992, seven successful general elections ${ }^{1}$ have been held with power alternating between two main political parties, namely the National Democratic Congress (NDC) and the New Patriotic Party (NPP). No incumbent seeking re-election lost in any of these elections other than the last. ${ }^{2}$ That defeat could be described as monumental because of the unprecedented margin of victory of the NPP over the ruling NDC. Commendably, over the past several decades many African countries have incorporated the development of four prominent democratic trends, namely the embrace of elections; the acceptance of constitutional norms; the emergence of free media and an active civil society; and the establishment of regional prodemocratic conventions and protocols (Gyimah-Boadi 2015, p. 101). A classic example is Ghana when it adopted the Constitution in 1992 and returned to a democratic government with a vibrant media and civil society, rule of law, as well as holding periodic elections. In this regard Ghana is seen as a model of democracy in Africa (Ayee 1997; Gyimah-Boadi 2001; Daddieh 2009; Abdulai \& Crawford 2010; Gyimah-Boadi \& Prempeh 2012; Gyimah-Boadi 2015).

This explains why the peaceful conduct of the nation's 2016 general election, which led to the electoral victory of the opposition NPP and the concession of the incumbent, was not a surprise to many watchers of democracy in Africa and across the globe. The NPP won the 2016 general election with $53.9 \%$ of the total valid votes counted while the incumbent NDC polled $44.4 \%$ (EC-Ghana 2016). In numerical terms, the NPP garnered 5716026 votes, the NDC obtained 4713277 votes, while four other minor parties and an independent presidential candidate shared $1.8 \%$ of the valid votes cast (EC-Ghana 2016). The NPP secured 169 out of

1 General elections were held in 1992, 1996, 2000, 2004, 2008, 2012 and 2016.

2 In the 2000 election that resulted in a transfer of power from the NDC to the NPP, the sitting government led by Jerry Rawlings was not eligible, per Ghana's 1992 Constitution, to stand for re-election because he had served two four-year terms in office. Similarly, in the 2008 general elections that led to the return of power from the NPP to the NDC, sitting president John Kufuor was also ineligible because he too had served two terms in office. President Mills of the NDC served only one term, from 2009-2012, and died while in office. His successor President John Mahama of the NDC served one term in office, from 2013-2016, but was defeated in his bid to seek re-election in a second term in the 2016 general election. His defeat could be described as monumental in the sense that it was the first time a sitting government had been defeated, and also because the enormous margin of defeat was unprecedented in the political history of Ghana since 1992. 
the 275 parliamentary seats, an almost two-thirds majority in Parliament, while the NDC garnered 106 seats. The defeat of the ruling NDC by the opposition NPP by over one million popular votes is what we describe as a monumental defeat. It is monumental because, in the political and electoral history of Ghana, no incumbent president seeking re-election has lost to the opposition party with such an enormous majority. Again, no opposition party has ever won an election against a ruling party at the first round without going through a run-off. It is this monumental defeat and fall of the NDC that the paper seeks to explain.

It must be noted that extant literature on Ghana's democracy and elections such as the work of Gyimah-Boadi (1991) focused on the transition to constitutional rule. Others have discussed the 1996, 2000, 2008 and 2012 presidential and parliamentary elections and have explained factors that may have accounted for electoral victories or defeats (Ayee 1997, 2002; Smith 2002; Daddieh 2009; GyimahBoadi 2001, 2009; Alidu 2014; Fobih 2008). Some scholars have also researched the role of the media, civil society, and state institutions in Ghana's democratic consolidation (Whitfield 2003; Arthur 2010; Gyampo \& Asare 2015). The role of third parties in consolidating Ghana's democratic practice and their abysmal performance in elections in Ghana, as well as the function of ethnicity in Ghana's electoral politics, have also been researched by scholars like Yobo \& Gyampo (2015) and Arthur (2009) respectively.

However, given that Ghana's 2016 general election is so recent, no detailed scientific interrogation, analysis or research has yet been conducted on the salient issues around this event. This is the first time an incumbent president seeking re-election has been defeated. Again, and as noted earlier, this is the first time an opposition party has won an election, not through a run-off, but in the first round with an unprecedented margin of victory. The unique nature of this study lies in the fact that it is arguably the first or at least one of the pioneering studies seeking to explain why the sitting president lost the 2016 elections. It delves into the factors accounting for the electoral victory of the opposition party in a firstround election. Regarding structure, the paper discusses the theoretical taxonomy and undertakes a historical/empirical sketch of election results in Ghana since 1992, highlighting the margins of defeat. It attempts an explanation of the NDC's defeat and proffers suggestions as to why the defeat was so substantial. Finally, it draws some conclusions and makes recommendations to further consolidate and strengthen the pillars of Ghana's democracy.

\section{THEORETICAL UNDERPINNING}

Voter behaviour forms the theoretical base of this study. Earlier studies on voter behaviour in general were grouped into the following three major schools of 
thought. First is the sociological model, which focuses on the influence of social factors in shaping voter behaviour (Lazarsfeld, Berelson, \& Gaudet, 1944 as cited in Antunes 2010, p. 146). Second is the psychosocial model, which assumes that party identification is the main factor behind the behaviour of voters. This model is attributed to the Michigan school, which has its major reference in the work of Campbell, Converse, Miller \& Stokes (1960) (ibid.). Third is the rational choice theory, also referred to as a model of economic voting, that emphasises variables such as rationality, choice, uncertainty and information. This is known as the Rochester school, attributed to Downs (1957) (ibid.).

Africa had three waves of democracy between the 1950s and the 1990s, the first of which witnessed several countries engaged in a struggle for national independence. Many of these post-independence countries leaned toward authoritarian regimes in the period between the 1960s and the 1990s. As a result, much of what was known of African politics during this period was conceptualised as clientelism, neo-patrimonialism, personalism, prebendalism, and rentier state (Lindberg 2004, p. 4). Therefore, studies on voter behaviour were produced under conditions of restricted competition in one-party authoritarian systems. Elections under these one-party systems did not allow voters a choice of who should rule; neither did they give voters a chance to influence policy directions. Nevertheless, since the end of the Cold War in 1989 which was symbolised by the fall of the Berlin wall in Germany, there have been multiparty elections in 44 out of 48 African countries for over 15 years (Lindberg 2004, 2006).

Indeed, in the 1990s there were several democratic reforms in Africa in what Huntington (1991) described as the third wave of democracy. This wave swept away many dictatorial regimes and their one-party systems that had subjugated several African states since independence in the 1960s. The third wave of democratisation was also occasioned by the failure of both military and civilian regimes to deal with poverty, unemployment, oppression and the lack of essential services such as healthcare, housing, and education. Moreover, these states were crippled with administrative inefficiencies, corruption, and socio-economic mismanagement (El-Khawas 2001). This forced many countries in Africa to return to democratic rule in the 1990s, with elections playing a major role.

The question, however, is what were the theoretical explanations regarding factors that shaped and influenced voter behaviour in Africa after the third wave of democracy? Several scholars have proffered responses. First is the rational choice model which suggests that voters are rational decision-makers who make their own calculations about the expected outcomes before casting their ballots for a candidate or party (Debrah 2016; Fair 1996; Fiorina 1981). Another explanation is the consumption benefits of voting, a democracy model which suggests that voters consider voting as a civic duty (Brennan \& Hamlin 2000; 
Kan \& Yang 2001). Although these two models elucidate positive voter turnout, they have been criticised for inferring that voter turnout is driven by factors not related to the principal element of the democratic process, which is the election of a government (Debrah 2016). This has led some scholars to suggest the ethical voter model, which states that although people serve their own self-interest, they also take into account other people's welfare (Camerer 2003; Debrah 2016). Lindberg \& Morrison (2008) used two categories for explaining voting behaviour; namely the evaluative and non-evaluative assessment models. In their view, the evaluative voter assesses political parties against representatives or candidates as one dimension and retrospective versus prospective judgments as another. Secondly, the non-evaluative model considers assessments made by clientelism and proxy voting.

Arguably the most comprehensive theoretical explanations of voting behaviour were presented by Andrew Heywood (2002, pp. 242-245). He identified four key conceptual models to explain voter behaviour in general. First is what he calls the party identification model. This model suggests that voting behaviours are influenced by robust connections to a particular political party leading to the party's stability and continuity. This is specifically with regards to the habitual patterns of voter behaviour, which are often constant over a long time. Second is the sociological model which links voter behaviour to group affiliation. It argues that voter behaviour is a reflection of the economic, social position, race and gender of the group to which the voter belongs to or identifies with. The third is known as the rational choice model, which suggests that voters are rational actors. In this regard, voter behaviour is based on the policies of the candidates. This model is based on the significance of issue-based voting and not party identification, sociological or ideological models. The fourth model is that of dominant ideology, which argues that political ideology is prominent in shaping voter behaviour.

Many scholarly works on elections and voting behaviour in Ghana have shown that the Ghanaian electorate vote for political parties rather than individual candidates (Ayee 1997, 2002; Boafo-Arthur (ed) 2006; Brierley \& Ofosu 2014; Daddieh 2009; Fobih 2008; Jockers, Kohnert \& Nugent 2010; Osei 2013; Smith 2002). This is what Heywood (2002, pp. 242-245) calls the party identification model in explaining voting behaviour. It places much prominence on strong attachment to a political party rather than an election candidate. This partisan alignment produces stability and continuity, specifically regarding habitual patterns of voting behaviour that are often sustained over a long time. In the view of Osei (2013) political party tradition provides a necessary context for comprehending the complexity of voting patterns in Ghana. It is this tradition that has created the ethnic, regional and socio-economic support base for the two main parties in Ghana, the NDC and the NPP (Kwakye 2013; Lindberg \& Morrison 2005). It is 
within this context that we suggest that the ordinary Ghanaian voter is influenced by the party identification model in deciding who to vote for in an election. This often leads to either rejection or endorsement of a political party during polls, particularly after a political party has been in power or opposition for two fouryear terms. This voting pattern has occasioned what is referred to as the two-term regime cycle of change ${ }^{3}$ in Ghana's current Fourth Republic.

Against this background, this paper seeks to explain the abysmal defeat of the incumbent NDC in Ghana's recent 2016 general election, which resulted in the peaceful transfer of power from President John Dramani Mahama to Nana Akufo-Addo of the NPP. This occasioned the third turnover of power during the Fourth Republic. Indeed, the 2016 elections offered Ghanaians an interesting situation whereby the electorate rejected the attempt by an incumbent president seeking a second term in office, which could have led to a third term for his party. ${ }^{4}$ In the following section of this paper we examine in depth the electoral history of Ghana's Fourth Republic.

\section{HISTORICAL BACKGROUND OF ELECTION RESULTS AND MARGINS OF VICTORY / DEFEAT IN GHANA'S FOURTH REPUBLIC}

Ghana's first general election in the Fourth Republic was held in 1992 with Jerry Rawlings of the ruling NDC being declared the winner, garnering $58.3 \%$ of the votes cast despite claims of electoral fraud. The main opposition NPP's candidate Albert Adu Boahen was placed second with $30.4 \%$ while the other candidates together polled 11.3\% of the total votes cast (Jeffries \& Thomas 1993, p. 331; Arthur 2010, p. 207; Yobo \& Gyampo 2015, pp. 8,11). The margin of defeat as shown in Table 1 was $27.9 \%$ of the valid votes for NDC, which possibly explains the main opposition's claims that the elections were rigged for the NDC. Part of the reason was that the Provisional National Defence Council (PNDC) - the military junta that had been in power for eleven years - organised and took part in the election as the NDC. In this regard, some have argued the PNDC government essentially handed over power to itself (Jeffries \& Thomas 1993; Ayee 1997; Gyimah-Boadi 2001). Hence the opposition parties, particularly the NPP, refused to accept the results, claiming the elections were rigged for the NDC and therefore boycotted the parliamentary elections held on 28 December 1992. The NDC secured 189

3 This describes a cycle of alternation of power relations whereby a political party wins elections consecutively for two terms and is rejected in the third poll, paving the way for the opposition also to win the next two consecutive elections. In Ghana, both the NDC and the NPP have, under the Fourth Republic, alternated power in eight-year intervals consisting of two terms in office respectively.

4 Before the 2016 elections, the NDC had held onto power for two consecutive terms; that is, the Mills / Mahama-led Administration (2009-2012) and Mahama-led administration (2013-2016). Hence, the 2016 election was incumbent President Mahama's second term bid. 
of the 200 seats, while smaller political parties aligned with the NDC held the remaining 11 seats. It was, therefore, evident that Ghana was a democracy only in name, and that some of the authoritarian tendencies from the PNDC era were still in force (Arthur, 2006).

Table 1

Presidential election results for the NDC and NPP since 1992

\begin{tabular}{|l|r|r|r|r|r|r|r|r|r|}
\hline $\begin{array}{l}\text { Political } \\
\text { Party }\end{array}$ & \multicolumn{70}{|c|}{ Percentage won } \\
\hline & $\mathbf{1 9 9 2}$ & $\mathbf{1 9 9 6}$ & \multicolumn{2}{|c|}{$\mathbf{2 0 0 0}$} & $\mathbf{2 0 0 4}$ & \multicolumn{2}{|c|}{$\mathbf{2 0 0 8}$} & $\mathbf{2 0 1 2}$ & $\mathbf{2 0 1 6}$ \\
\hline & & & $\begin{array}{c}\text { Round } \\
1\end{array}$ & $\begin{array}{c}\text { Round } \\
2\end{array}$ & & $\begin{array}{c}\text { Round } \\
1\end{array}$ & $\begin{array}{c}\text { Round } \\
2\end{array}$ & & \\
\hline NDC & 58.3 & 57.4 & 44.5 & 43.9 & 44.9 & 47.9 & 50.2 & 50.7 & 44.40 \\
\hline NPP & 30.4 & 39.6 & 48.2 & 56.9 & 52.5 & 49.13 & 49.8 & 47.7 & 53.85 \\
\hline Variations & 27.9 & 17.8 & 3.7 & 13.0 & 7.6 & 1.23 & 0.4 & 3.0 & 9.45 \\
\hline
\end{tabular}

Source: authors' computation from the Electoral Commission of Ghana. ${ }^{5}$

Subsequently, in 1996 the NDC won both the presidential and parliamentary elections with a convincing majority. Rawlings secured 4099760 votes out of the 7225161 valid votes cast, representing 57.4\%, while the NPP led by John Kufuor obtained 2825715 votes representing 39.6\%, with the other smaller parties obtaining 3\% of the rest of the votes (Ayee 1997). The margin of defeat this time was $17.8 \%$ for similar reasons to those of the 1992 general election. The NDC won 134 out of the 200 seats with the NPP securing 60 seats. The People's Convention Party (PCP) won 5 seats, and the People's National Convention (PNC) captured 1 seat (Arthur, 2010). Similar reasons for the NDC's 1992 victory have been adduced for its 1996 victory (ibid.).

In 2000, Jerry Rawlings could not contest again since he was barred from standing a third time in terms of the 1992 Constitution. His vice-president Prof J.E.A. Mills contested the elections on the NDC's ticket but lost to the opposition NPP, led by John Kufuor after a run-off. In the first round, John Kufuor secured 48.2\% while Mills polled 44.5\%. Given that neither obtained the 'fifty percent plus one vote' threshold per constitutional requirement, a run-off was held on 28 December 2000. John Kufuor of the NPP won with 56.9\% of the votes with the NDC candidate polling $43.9 \%$. The margin of defeat was $13 \%$ as shown in Table 1.

5 Table 1 shows the presidential results of the two major political parties NPP and NDC in Ghana's Fourth Republic. It also points out the variation in percentages of the defeat between the two parties from 1992 to 2016. 
The reason for this margin was the support the NPP obtained from almost all the opposition parties during the second round of elections and the general call for change in Ghana as result of regime fatigue. The NPP captured 100 of the parliament's 200 seats and the NDC obtained 92, while independent and minor political parties had the remaining eight seats (Gyimah-Boadi 2001, p. 103).

In the 2004 general elections, John Kufuor was re-elected as president with $52.5 \%$ of the total votes cast, while J.E.A. Mills of the NDC received $44.9 \%$ and the margin of defeat was $7.6 \%$. Clearly, a majority of Ghanaians supported the second term bid of the NPP to complete the two-term cycle (eight years) Although parliamentary seats had been increased from 200 to 230, the NPP retained its majority with 128 parliamentary seats, while the NDC won 94 seats. The PNC won 4 seats, Convention People's Party (CPP) won 3, and an independent candidate won the remaining seat (Fobih 2008).

After two terms i.e. eight years' rule by the NPP, the NDC was re-elected to power. Of the 230 parliamentary seats, the NDC won 114 as against 107 by the NPP. In the presidential race, Nana Akufo-Addo of the NPP polled $49.1 \%$ of the total votes cast while NDC's J.E.A. Mills obtained $47.9 \%$ of the total valid votes, as shown in Table 1. Again, just as in the 2000 general election, the 7 December 2008 presidential polls failed to produce a clear winner at the first ballot. Hence a runoff of the presidential election was held on 28 December 2008 (Yobo \& Gyampo 2015, p. 13). After the runoff, the NDC won with 50.2\% of the votes while NPP obtained $49.8 \%$. As shown in Table 1, the margin of defeat was $0.4 \%$, the smallest margin of defeat recorded in the electoral history of Ghana's Fourth Republic. Nonetheless, majority of Ghanaians felt that eight years of NPP was enough and what is called regime fatigue had set in. Hence a majority of the electorate had called for change, which led to the NPP handing over power to the NDC.

Ghana's sixth presidential and parliamentary elections were held concurrently on 7 December 2012, with the incumbent president, John Dramani Mahama, ${ }^{6}$ narrowly winning with $50.7 \%$ of the votes and the main opponent, Nana Akufo-Addo of the NPP, obtaining 47.7\% of the votes. As shown in Table 1, the margin of defeat was $3 \%$ in favour of NDC, signifying the support for continuity of the NDC administration after the death of President Mills and the assumption of office by John Mahama as president. This result confirms our position that Ghanaians vote for political parties and thus gave the NDC a second term. The NDC further won a majority of 148 seats in parliament while the NPP secured 123 seats. The remaining seats were shared among independent candidates ( 3 seats), and the PNC (1 seat) (Brierley \& Ofosu 2014; Yobo \& Gyampo 2015, p. 15).

6 John Mahama, who had been the Vice-President, succeeded President Mills who died in his first term in the lead-up to the 2012 general election. 
Following the declaration of the 2012 election results, the opposition NPP filed a petition at the Supreme Court, arguing that the 2012 election was marred by widespread electoral malpractices and fraud (Alidu 2014). The '2012 Election Petition', as it became popularly known, lasted for eight months until August 2013. Notwithstanding the prolonged legal battle, the verdict of the justices of the Supreme Court upheld President John Dramani Mahama as being validly elected. Indeed this was a major test of Ghana's democratic consolidation, and Ghana undoubtedly survived the possibility of post-election conflict when the opposition leader Nana Akufo-Addo accepted the decision of the Supreme Court even though he openly disagreed with the verdict (GhanaWeb 2013).

Ghanaians returned to the polls again on 7 December 2016 for the seventh consecutive time under the current Fourth Republic Constitution. This election was highly contested by the two major political parties in Ghana, the NDC and the NPP. Nevertheless, other political parties including the Convention Peoples' Party (CPP), the Peoples' National Convention (PNC), the Progressive People's Party (PPP), the National Democratic Party (NDP) and an independent candidate also participated. The EC had disqualified some aspirant presidential candidates who did not meet the requirements as stipulated in the Constitutional Instrument (C.I.) 94 for the conduct of the elections. In all, seven candidates gained ballot access for the presidential contest after a series of disqualifications and court actions (Adogla-Bessa 2016; Frimpong 2016).

At the end of polling, the opposition NPP led by Nana Akufo-Addo won a landslide victory with 53.9\%, at the first round, unseating the incumbent President John Dramani Mahama of the NDC who managed $44.7 \%$ of the total valid votes as shown in Table 1.7 In Parliament, the NPP won overwhelming majority of 169 seats while the NDC garnered 106 of the total 275 seats (Kwakofi 2016b). With this historical background, two important questions are worth asking. Firstly, why did the NDC with a sitting president lose the elections with a $9.5 \%$ margin? Secondly, why was the defeat so monumental? These are discussed in subsequent sections of the paper.

\section{ACCOUNTING FOR NDC'S DEFEAT IN THE 2016 GENERAL ELECTIONS}

The acme factor that accounted for the NDC's defeat in the 2016 polls is regime fatigue. After being in government for eight years, Ghanaians were simply tired of the NDC and wanted a change. Indeed, the history of elections in Ghana since

7 The 1992 and 1996 elections results show a massive win for the incumbent NDC. Again, in the 2000 presidential contest, the opposition NPP won in the second round of voting with $13 \%$, with the support of third parties. Similarly, the opposition NDC unseated the incumbent NPP in the 2008 run-off election with a slim margin of $0.4 \%$. 
1992 is a history of a two-term regime cycle of change. This has been consistently demonstrated since the inception of the Fourth Republic in $1992 .{ }^{8}$

With the two-term regime cycle of change ingrained in the minds of many Ghanaians, it was going to be an uphill task for the ruling NDC to break the chain irrespective of the massive proactive, temporary or artificial socio-economic interventions the party implemented to deal with the challenges confronting the people. In this regard, the rational socio-economic interventions by the NDC including the massive infrastructural development even angered many Ghanaians who were simply tired of the NDC and wanted a change.

Being cognisant of the political psyche of the Ghanaian electorate, the NDC's 2016 campaign sought to entrench in public minds that the 2016 election was only a second term bid for President John Mahama. To many Ghanaians, this was sheer propaganda, as it was also a third term bid for the ruling NDC. Given that Ghanaians vote for political parties and not candidates, it was clear that they were going to reject the NDC's third-term bid and by extension jettison President Mahama's second-term bid. So the NDC was clearly going to lose the 2016 general elections as a result of regime fatigue occasioned by the principle of the two-term regime cycle of change.

Secondly, the history of voter behaviour in Ghana's Fourth Republic shows that most of the electorate votes on the party identification model as pointed out by Heywood (2002); this is supported by several studies (Ayee 1997, 2002; Boafo-Arthur ed. 2006; Brierley \& Ofosu 2014; Daddieh 2009; Fobih 2008; Jockers, Kohnert \& Nugent 2010; Osei 2013; Smith 2002). As Osei (2013) pointed out, in Ghana the political party tradition has led to the creation of ethnic, regional and socio-economic support bases for the two major parties in Ghana known as the NDC and the NPP (Kwakye 2013; Lindberg \& Morrison 2005). Similarly, Lindberg \& Morrison (2005, p. 571) show that since the 1992 general election a dominant twoparty partisan alignment has characterised the Ghanaian political environment.

In addition, Whitfield (2009) argues that since the inception of the Fourth Republic, Ghana's keenly competitive elections are as a result of a de facto two-party system in which voters and the political elites are mobilised around two political traditions. These traditions offer ideological images, founding mythologies and political styles for the parties. This makes Ghana different from other African countries where parties are formed around leaders, who bring their popular support base with them. Furthermore, he argues that elections are not controlled by ethnic politicisation, since the two main parties in Ghana (NPP and NDC) have a strong political support base in most regions with party identification

8 Both the NDC and the NPP have, under the Fourth Republic, alternated power in eight-year intervals consisting of two terms in office. 
being strongly based on cross-cutting social cleavages, and ethnicity playing only a small part.

Having noted this, we caution that Ghanaian electorates should desist from voting along purely partisan lines and rethink the need to vote on rational issues as articulated by Heywood (2002) in his postulations on the rational choice model of voting. With this model, voting is seen as a rational act. In this regard, voters stress the importance of issues-based voting such as the quality of candidates, policies, and performance of the candidate or political party. Even though President Mahama of the NDC had served for only one term and had pleaded with Ghanaians to be given a second term, Ghanaians objected to this claim and voted against the NDC which had been in power for eight years. In this regard, instead of looking at the person of President Mahama, the electorates were interested in how long his party had been in office.

There can however be no development without some stability. A developing country like Ghana cannot afford to change governments every eight years just because of regime fatigue occasioned by the two-term regime cycle of change. Just because a political party has been in power for eight years cannot be sufficient reason for changing it. Indeed, change for change's sake cannot be a desirable ingredient for democratic consolidation and development. Many Ghanaians lament that they attained independence around the same time as Malaysia and yet lag behind Malaysia's development. What they ignored is the regime stability Malaysia enjoyed for a long time. Mahathir Mohammad and the United Malays National Organization (UMNO) of Malaysia ruled for 22 years (1981-2003) by forming complex electoral and democratic alliances with other parties. The UMNO was maintained for over two decades due to the transformational economic policies it implemented in seeking to make Malaysia a fully developed country within 30 years (Wain 2009). These economic interventions were successful in reducing poverty and income inequalities. Indeed, in our view changing regimes simply because they have lasted for eight years is irrational and may be counterproductive to Ghana's developmental aspirations. Nonetheless, apart from regime fatigue and the two-term cycle regime change of eight years being the major factor contributing to the defeat of NDC, the question now, is what made the defeat monumental? The next section attempts to offer some responses.

\section{WHAT MADE THE DEFEAT MONUMENTAL?}

In the quest to investigate the monumental defeat of the NDC, myriad factors have been identified. To begin with, the poor economic performance of the NDC regime has been identified as a key factor accounting for its electoral loss in the 2016 polls (Ansah 2016b). Despite some progress having been made by the Mahama administration in both the macro- and microeconomic environments, 
the Ghanaian economy is not resilient (The Economist 2016). Even though urban poverty decreased, rural poverty worsened considerably. Gross Domestic Product (GDP) growth had fallen from $14 \%$ in 2011 to $4.1 \%$ in 2015. The fiscal balance also deteriorated from -7.1\% of GDP to -12.4\% of GDP by 2014 (Kwakye 2014; Wiafe 2016). The Ghana cedis plummeted regularly, falling from US $\$ 1: 1.64$ cedis in 2011 to US \$1:4:32 cedis by the time Ghanaians went to the polls in December 2016 (GBN 2012; TradingEconomics 2016).

The prolonged erratic power supply, which became known in local parlance as dumsor, and its attendant economic consequences, is not discrete (Arthur 2016). These power crises affected the cost of production because many companies had to rely on power generators for energy. Other companies faced severe equipment breakdown due to the frequent power outages. In addition, Ghanaians were economically deprived due to a high unemployment rate, yet the incumbent NDC downplayed the issue insisting that more jobs had been created in the construction sector as a result of the incumbent's infrastructure development drive. All these economic downturns resulted in a high cost and low standard of living, which pushed the NDC closer to electoral misfortune. Also, the NDC lost favour with the Ghanaian working class, particularly public sector workers, for its indifference to numerous labour problems. The concomitant and frequent labour unrest vilified the NDC administration as being insensitive to the plight of workers. President Mahama's own metaphor of 'dead goat don't fear knife' amplified this sentiment of insensitivity (Gadugah 2015).

In addition to these economic crises, there were frequent cases of actual and perceived corruption with which the NDC administration wrestled unsuccessfully. Even though the Mahama Administration launched the National Anti-Corruption Action Plan (2015-2024), it was implemented too late to redeem the NDC from the monumental electoral defeat by NPP on 7 December 2016. Key among the many corruption scandals that rocked the nation during the Mills/Mahama eight year regime (2009-2016) were the Savannah Accelerated Development Authority (SADA) debacle ${ }^{9}$, the misappropriation of Ghana Youth Employment and Entrepreneurial Development Agency (GYEEDA) funds, and the SUBAH deal (Abdul-Fatawu 2016). ${ }^{10}$ The rest are the Alfred Woyome's GH 51

9 An Auditor-General's report revealed huge sums of taxpayers' money misappropriated by this body. SADA was a governmental initiative to address extreme poverty in the Northern part of Ghana but failed woefully owing to administrative lapses and financial malfeasance.

10 The SUBAH deal is a story of how the Ghana Revenue Authority entered into a contract with Subah Info-Solutions for the electronic monitoring of mobile networks to confirm whether they are truthful in declaring all their taxes. Under the contract, SUBAH was supposed to connect some physical nodes to the equipment of telecom companies to monitor revenues that are supposed to be paid by the telecoms, but this was not done. Subah InfoSolutions was, nonetheless, paid GH\$74 million from 2010-2012, after the company claimed to have adopted manual monitoring. 
million judgment debt case, and the issue of financial malfeasance surrounding the 2014 World Cup appearance of the Black Stars which led to the formation of Justice Dzamefe Committee (Arthur 2016). ${ }^{11}$ The opposition NPP thus capitalised on these corruption scandals in the incumbent NDC administration, and made a key campaign pledge to fight corruption when elected (Tornyi 2015). This campaign message of the NPP resonated well with most of the voting public, leading to the mass rejection of the NDC at the 2016 polls. Hence, the victory of the NPP over the NDC in the 2016 polls is partly attributed to the latter's lethargic attitude towards fighting corruption, and the former's resolve to combat corruption (Ansah 2016b). Ex-president John Rawlings, founder of the NDC, has maintained that 'impunity and corruption caused NDC's defeat' in the 2016 polls (Ansah 2016a).

Furthermore, a few months before the elections on 7 December 2016 the Mahama-led NDC took some unpopular decisions, which angered many Ghanaians. These included the cancellation of teachers' and nurses' trainee allowance and the August 2016 presidential pardon granted to three people (popularly known as the Montie Three) - a radio host and two panellists of an Accra-based FM station who were jailed for four months by the Supreme Court for criminal contempt (scandalising the Supreme Court) - and released barely a month after being jailed (Kwakofi 2016a). Other unpopular last-minute decisions of the NDC government included a notice filed by the Attorney General's Department at the Supreme Court to discontinue a case against businessman Alfred Agbesi Woyome in the controversial GH $\$ 51$ million judgment debt saga. ${ }^{12}$ This despite the order by the Supreme Court in 2014 for Mr. Woyome to refund the GH\&51 million fraudulently taken from the state (Allotey 2016). This single act of the NDC administration reflected its lethargic attitude towards retrieving misappropriated public funds, and to a large extended the fight against corruption.

Consequently, there was both evidence and perception of arrogance, rudeness, and disrespect on the part of some ministers and officials of the NDC. This made President Mahama and the NDC over-confident creating an impression of immunity, invincibility, and complacency. This arrogance coupled with the perceived division in the leadership of the NPP made the Mahama-led NDC complacent. In September 2016, a few months before the December elections, astute Ghanaian journalist Paul Adom-Otchere interviewed President Mahama on Good Evening Ghana, a weekly television vision show on Metro-TV. In the interview they discussed various subjects including some of the issues around

11 The Committee became necessary after Ghana's Black Star exit in the 2014 World Cup tournament. The exit crowned scandalous events off the field including an embarrassing airlift of 3 million US dollars in cash on a presidential jet, an act that made Ghana a subject of global ridicule.

12 See more at http: / / citifmonline.com/2016/11/02/ag-discontinues-woyomes-ghc51m-judgementdebt-case/ 
the 2016 elections campaigns and the NDC's assertions that the NPP is a divided and not a united party. In part response President Mahama stated that:

Of course, NPP is divided ... my opponent's [Akufo-Addo] track record shows he is not able to bring his own party together ... today it's the truth people can't criticize Akufo-Addo in NPP if you criticize him they will suspend you or they will sack you or his attack dogs will set on you. Ask people in the NPP; there are quite a good number of people in the NPP. NPP are quiet they can see the bus [NPP] is going to crush but if they say it they would attack them and so they are quiet waiting for the bus to crush and when it crushes. I said they will take the bus to Kokompe [a hub for car repairs] and repair it and put it on the road for 2021. (Adom-Otchere 2016)

Also, in the aftermath of the 2016 polls former President John Rawlings of the NDC emphasised that: 'It was obvious a long time ago that we wouldn't make it. Our general negativity, impunity, disrespect and corruption was taking us further and further downhill. About the time when most were living in the painful reality with stress and anger, that's when some of us chose to be more impervious to reality' (Ansah 2016a).

Subsequently, the NPP's campaign message based on their 2016 manifesto was more appealing to many voters than the NDC's campaign message. Nana Akufo-Addo of the NPP campaigned on 'change, job creation linked to the industrialization of the economy and the modernization of agriculture' and the 'incompetence of the Mahama-administration' (NPP-Manifesto 2016). On the other hand, President Mahama and the NDC campaigned on 'continuity', 'unprecedented infrastructure achievements' and 'changing lives and transforming Ghana' (NDCManifesto 2016). Evidently, with an ailing economy, high level of unemployment and high utility bills to pay, many Ghanaians found the NPP's campaign message of job creation, industrialisation, and modernisation of agriculture more attractive than that of the NDC. Indeed NDC's 2016 campaign motto of 'Forward Ever, Backwards Never' was not as appealing as the NPP's 'Ghana Must Work Again' and 'Arise for Change' (NDC-Manifesto 2016; NPP-Manifesto 2016).

Besides, the NDC failed to brand itself prominently especially in communicating its core campaign messages and ideas. The Mahama-led NDC focused most of their campaign on attacking the personality of the opposition leader instead of focusing on an issues-based campaign (Akwa 2016; Daily Guide Africa 2016). Instead of responding to these claims by the NDC, Nana Akufo-Addo and the NPP clearly articulated their core campaign messages and slogans such as 'Free Senior High School (SHS) education', 'one district one factory' and 'one 
village one dam' (Daily Guide Africa 2016; NPP-Manifesto 2016). The insistence of President John Mahama not to reinstate the teachers' and nurses' trainee allowance compared to the opposition NPP candidate's resolution to restore the same was more alluring to that cross-section of the voting public, mainly, current and future students of the colleges (Asare 2015; Myjoyonline.com 2016). In comparison the NPP 2016 campaign provided hope whereas the NDC prosecuted several politically inexpedient campaigns, lacking the efficacy of their 2012 Better Ghana Agenda campaign.

Moreover, the NDC's abuse of incumbency was evident during the 2016 election campaign. It used expensive advertisements in the media, building huge billboards and vote-buying (Gadugah 2016). During the 2016 campaign, the NDC overtly reverted from its successful 2008 and 2012 approach of door-to-door campaigning, towards adopting an elitist approach of gigantic billboards, musical concerts, and extravagant expenditure on influential chiefs that endorsed President Mahama's second term bid. This approach resulted in the public perception of President Mahama as a friend to chiefs rather than the vast majority of the people who constitute the voting public. Moreover, it is asserted that the campaign fund was highly centralised and did not trickle down to a grassroots campaign. Also, there were several instances where President Mahama used a helicopter to campaign in the Northern Region and Western Regions, while the NPP's Nana Akufo-Addo and his team were stuck on the road due to poor road accessibility for these communities (Daily Guide 2016; Obempong 2016).

Furthermore, there was a high level of apathy and dissatisfaction in the domain of the NDC's core constituencies as evident in the 'skirt and blouse' voting pattern in many pro-NDC constituencies. These included the Lawra and the Nandom Constituencies in the Upper West region; the Krachi East Constituency in the Volta region; and the Zabzugu and the Salaga South Constituencies the Northern region (EC-Ghana 2016). This was partly due to the inability of the party's leadership to resolve the many intra-party wrangles after the primaries, and the NDC government's bias towards urban development projects. The NDC is believed to draw core support more from rural areas than from urban dwellers due to its ideological posture of social democracy (Kwakye 2013; Lindberg \& Morrison 2005). Nevertheless, most of the infrastructural achievements the party prided itself on had an urban bias, such as the magnificent Kotokuraba and Kejetia central markets, the Kasoa and the Kwame Nkrumah Circle Inter-Change, the Ridge Hospital project and the University of Ghana Teaching Hospital.

This led to dissatisfaction among many predominantly pro-NDC rural communities. Closely related was the NDC's inability to mobilise its core base to turn out on voting day, particularly the Volta region and the three Northern regions of Ghana viz the Northern region, the Upper East region and the Upper 
West region. This, debatably, caused the electoral misfortunes of the party. The core base of NDC supporters felt mistreated by the ruling NDC government. For them, their consistent support for the ruling NDC had not been reciprocated regarding developmental projects under the John Mahama-led NDC administration. This sentiment was trumpeted by many pro-NDC communities who protested and chanted slogans such as 'No road, no vote!', 'No electricity, no vote!' during the height of the electioneering season. Thus the voter turnout in notable NDC strongholds, particularly in the Volta region, was remarkably low; around $61.6 \%$ as against 75.7\% in 2012 (Alidu 2014; EC-Ghana 2016).

Nevertheless, elements within the opposition NPP uphold that this was a true reflection of the actual voter population of the region..$^{13}$ They explained that the seemingly low voter turnout in the Volta region during the 2016 polls is as a result of the activities of NPP vigilante groups along the (porous) borders of the eastern corridor (the Ghana-Togo border) which prevented non-Ghanaian illegal registered voters from voting or perpetuating electoral fraud, which had allegedly been the status quo. More so, we believe that the high incidence of rejected/ spoilt ballot recorded in these regions (Volta, Upper West, and Upper East) was largely deliberate and not erroneous. The act is described as an unorthodox mode of disapproving the incumbent NDC, though with reluctance to endorse the opposition NPP in an election. Strikingly, some Electoral Commission officials consulted for this study remarked that most of these rejected ballots were not thumb-printed at all, which is a protest vote of some sort. The instance of Ketu South Constituency, a major stronghold of the NDC where over 1,300-rejected/ spoilt ballots were recorded, is a clear case in point (EC-Ghana 2016).

Finally, in this era of globalisation, the sway of global electoral politics as a contributory factor to the NDC's loss in the 2016 polls cannot be downplayed. Around the same period that Ghanaians went to the polls, Nigeria, the United States and the Gambia (on 28 March 2015, 8 November 2016 and 1 December 2016 respectively) had all voted out their incumbents. This wind of regime change which swept across the globe indirectly prejudiced the voting behaviour of the Ghanaian electorates. The dynamics of Nigeria's 2015 polls, in particular, had many interesting comparisons with Ghana's 2016 polls. Firstly, both incumbent presidents John Mahama of Ghana and Jonathan Goodluck of Nigeria assumed the presidency under similar circumstances. They continued the unexpired term of their bosses under whom they had served as vice presidents, and had subsequently contested and won an ensuing election and served their first term as presidents.

13 Other schools of thought also argue that the low recorded nationwide voter turnout gives credence to earlier claims which suggested that the national electoral register was bloated. 
The opposition leader Muhammadu Buhari of Nigeria was an identical age as the opposition NPP's Nana Akufo-Addo of Ghana; both were septuagenarians. The elderly Buhari's landslide victory over the youthful and incumbent Goodluck in March 2015 polls dispelled the propagandised notion that Nana Akufo-Addo of the NPP was too old for the presidency, whilst at the same time offered a cue that John Mahama of the NDC could be rejected as the case had been in Nigeria (Al Jazeera 2015; BBC News 2015).

\section{CONCLUSION AND WAY FORWARD}

The 2016 general elections have yet again proved that Ghana is a bastion of democracy in Africa. In climbing the ladder of democratic progression, several deficits must be addressed. First of all, voter behaviour based solely on political parties and not on the quality of candidates contesting an election is irrational and must be checked. Secondly, changing regimes merely because they have lasted for eight years is also irrational and if not dealt with, may be counterproductive to development. Ghana may therefore take some lessons from Malaysia in maintaining political stability where necessary. In achieving stability for development, commitment to implementing properly considered developmental programmes would be critical in dealing with regime fatigue and upsetting the two-term regime cycle of change. In this regard, the NPP regime has to work to revive Ghana's failing economy; deal with pervasive institutional malaise; tackle corruption frontally; deal with winner-takes-all politics that polarises the country; provide an enabling environment for the private sector to thrive; create employment opportunities; and many more as indicated in the NPP's 2016 Manifesto (NPP-Manifesto 2016). In essence the Akufo-Addo administration must religiously adhere to its campaign promises in order to secure a second term in office and beyond.

\section{ACKNOWLEDGMENT}

We would like to thank Dr. Michelle Kwok for her comments at the earlier stage of this paper. We are also grateful to the managing editor and anonymous reviewers for their inputs. 


\section{- REFERENCES}

Abdulai, A-G \& Crawford, G 2010, 'Consolidating Democracy in Ghana: Progress and Prospects?', Democratization, vol. 17, no. 1, pp. 26-67 https://doi. org $/ 10.1080 / 13510340903453674$

Abdul-Fatawu, F 2016, October 5, 'Fighting Corruption In Ghana; How The President Mahama Led NDC Betrayed And Deceived Ghanaians', retrieved 4 January 2017 from https://www.modernghana.com/news/724508/ fighting-corruption-in-ghana-how-the-president-mahama-led-n.html

Adogla-Bessa, D 2016, October 10, 'Why Nduom and 12 Other Presidential Aspirants Were Disqualified', retrieved from http://citifmonline. com/2016/10/10/ why-nduom-and-12-other-presidential-aspirants-weredisqualified/

Adom-Otchere, P 2016, 'President John Mahama on Good Evening Ghana', YouTube, viewed 5 January 2017, <https://www.youtube.com/ watch? $\mathrm{v}=\mathrm{GNhfwM}$ yhcM $>$.

Akwa, NS 2016, August 15, "Presidency not for short people": Comment a Figure of Speech - NDC', retrieved 4 January 2017, from http: / / www.myjoyonline.com / politics / 2016/ August-15th / presidency-not-for-short-peoplecomment-a-figure-of-speech-ndc.php

Al Jazeera 2015, April 5, 'Buhari Secures Historic election victory in Nigeria', retrieved 4 January 2017, from http:/ / www.aljazeera.com/news/2015/03/ opposition-party-declares-victory-nigeria-election-150331135603507.html

Alidu, SM 2014, 'Party Politics and Electoral Malpractice in Ghana's Election 2012', viewed 20 December 2016, <http: / / www.journalrepository.org/media/journals/JSRR_22/2014/Apr/Alidu3112014JSRR9223_1.pdf>.

Allotey, GA 2016, November 2, 'AG Discontinues Woyome's GHc51m Judgement Debt Case', Ghana News, retrieved 4 January 2017, from http: / citifmonline.com/2016/11/02/ag-discontinues-woyomes-ghc51m-judgementdebt-case/

Ansah, M 2016a, December 13, 'Marian Ansah Writes: Why Mahama Lost the Election', Ghana News, retrieved 4 January 2017, from http://citifmonline.com/2016/12 / 13/ marian-ansah-writes-why-mahama-lost-theelection/\#sthash.NjjBaxqm.oHS9cgJm.dpuf

Ansah, M 2016b, December 31, 'Impunity and Corruption Caused NDC's defeat - Rawlings', retrieved 4 January 2017, from https:// citifmonline. com/2016/12/31/impunity-and-corruption-caused-ndcs-defeat-rawlings/

Antunes, R 2010, 'Theoretical Models of Voting Behaviour', Exedra, vol. 4, pp. 145170. 
Arthur, A 2016, December 6, 'Ghana Election: Can "Mr Power Cut" John Mahama win a Second Term?', BBC News, retrieved 4 January 2017, from http:// www.bbc.com/news/world-africa-18980639

Arthur, P 2009, 'Ethnicity and Electoral Politics in Ghana's Fourth Republic', Africa Today, vol. 56, no. 2, pp. 45-73.

Arthur, P 2010, 'Democratic Consolidation in Ghana: the Role and Contribution of the Media, Civil Society and State Institutions, Commonwealth $\mathcal{E}$ Comparative Politics,vol.48,no.2,pp.203-226,https:/ / doi.org/10.1080/14662041003672510 Asare, IA 2015, Akufo-Addo To Restore Nursing Training Allowance, viewed 4 January 2017, <https: / / www.modernghana.com/news / 641645/akufo-addo-to-restore-nursing-training-allowance.html>.

Ayee, JRA (1997), 'The December 1996 General Elections in Ghana', Electoral Studies, vol. 16, no. 3, pp. 416-427.

Ayee, JRA (2002), 'The 2000 General Elections and Presidential Run-off in Ghana: An Overview', Democratization, vol. 9, no. 2, pp. 148-174.

BBC News 2015, 'Nigeria Election: Muhammadu Buhari Wins Presidency' April 1, retrieved 4 January 2017, from http://www.bbc.com/news/world-africa-32139858

Boafo-Arthur, K (ed.) 2006, Voting for Democracy in Ghana: The 2004 Elections in Perspective, Freedom Publications, Accra, Ghana.

Brennan, G\& Hamlin, A2000, Democratic Devices and Desires, Cambridge University Press, Cambridge.

Brierley, S \& Ofosu, G 2014, 'The Presidential and Parliamentary Elections in Ghana, December 2012', Electoral Studies, 35, pp. 382-385, https://doi. org/10.1016/j.electstud.2014.02.005

Camerer, CF 2003, Behavioral Game Theory. Experiments in Strategic Interaction, Princeton University Press, Princeton, New Jersey.

Daddieh, CK 2009, 'The Presidential and Parliamentary Elections in Ghana, December 2008', Electoral Studies, vol. 28, no. 4, pp. 642-647.

Daily Guide 2016,' Bad Roads Force Mahama to Fly Helicopters', viewed 5 January 2017, <http:/ / ghana-news.adomonline.com/politics/2016/ August-27th/ bad-roads-force-mahama-to-fly-helicopters.php $>$.

Daily Guide Africa 2016, 'Nana Jabs NDC Over Insults', viewed 4 January 2017, $<\mathrm{http}$ // / dailyguideafrica.com/nana-jabs-ndc-over-insults/>.

Debrah, E 2016, 'The Ghanaian Voter and the 2008 General Election', Politikon, vol. 43, no. 3, pp. 371-387.

Downs, A 1957, 'An economic theory of political action in a democracy', The journal of political economy, pp. 135-150.

Electoral Commission of Ghana 2016, 2016 Presidential Results, viewed 20 December 2016, <http:/ / www.thumbsapp.com.gh/ > . 
El-Khawas, MA2001, 'Democracy in Africa: Problems and Solutions', Mediterranean Quarterly, vol. 12, no. 3, pp. 85-97.

Fair, RC 1996, 'Econometrics and presidential elections', The Journal of Economic Perspectives, vol. 10, no. 3, pp. 89-102.

Fiorina, MP 1981, Retrospective Voting in American National Elections, Yale University Press, New Haven.

Fobih, N 2008, 'Political Parties and Democratic Development in Ghana: From Transition to Consolidation and Beyond', PhD thesis, Queen's University, Kingston Ontario, retrieved from http:/ / qspace.library.queensu.ca/jspui/ handle/1974/13944

Frimpong, ED, 2016, October 11, 'EC Disqualifies - Mahama, Nduom, Ayariga, Akua Donkor \& others', Graphic Online 2016, retrieved 26 December 2016, from http://www.graphic.com.gh/news/general-news/odike-ayarigamahama-disqualified.html

Gadugah, N 2015, 'I have dead goat syndrome Mahama tells Ghanaians', MyJoyOnline, viewed 4 January 2017, <http://www.myjoyonline.com/ politics / 2015 / March-11th/i-have-dead-goat-syndrome-mahama-tellsghanaians.php>.

Gadugah, N 2016, August 18, 'NDC Most Guilty of Vote Buying- CDD Survey', MyJoyOnline, retrieved 4 January 2017, from http://www.myjoyonline. com / politics / 2016 / August-18th / ndc-most-guilty-of-vote-buying-cddsurvey.php

Ghana Business News 2012, September 12, 'Ghana Cedi Falls 18\% Against US Dollar First Eight Months of 2012 - BoG', retrieved 4 January 2017, from https:/ / www.ghanabusinessnews.com/2012/09/12/ghana-cedi-falls-18-againstus-dollar-first-eight-months-of-2012-bog/

GhanaWeb 2013, 'Akufo-Addo: 'I disagree with SC's verdict but I accept', viewed 26 December 2016, <http://www.ghanaweb.com/GhanaHomePage/ News Archive/ Akufo-Addo-I-disagree-with-SC-s-verdict-but-Iaccept-284117>.

Gyampo, R EV \& Asare, B 2015, ‘The Church and Ghana's Drive Toward Democratic Consolidation and Maturity', Journal of Church and State, vol. 59, no 1. https: / / doi.org/10.1093/jcs / csv095

Gyimah-Boadi, E 1991, 'Notes on Ghana's Current Transition to Constitutional Rule', Africa Today, vol. 38, no. 4, pp. 5-17.

Gyimah-Boadi E 2001, 'A Peaceful Turnover in Ghana', Journal of Democracy, vol. 12, no. 2, pp. 103-117.

Gyimah-Boadi, E 2009, 'Another Step Forward for Ghana', Journal of Democracy, vol. 20, no. 2, pp. 138-152. 
Gyimah-Boadi, E 2015, 'Africa's Waning Democratic Commitment', Journal of Democracy, vol. 26, no. 1, pp. 101-113.

Gyimah-Boadi, E \& Prempeh, HK 2012, 'Oil, Politics, and Ghana's Democracy', Journal of Democracy, vol. 23, no. 3, pp. 94-108.

Heywood, A 2002, Politics (2 ${ }^{\text {nd }}$ Edition), Palgrave Macmillan UK, London.

Huntington, SP 1991, 'Democracy's Third Wave', Journal of Democracy, vol. 2, no. 2, pp. 12-34.

Jeffries, R \& Thomas, C 1993, 'The Ghanaian Elections of 1992', African Affairs, vol. 92, no. 368, pp. 331-366.

Jockers, H, Kohnert, D \& Nugent, P 2010, 'The Successful Ghana Election of 2008: A Convenient Myth?', The Journal of Modern African Studies, vol. 48, no. 1, pp. 95-115.

Kan, K \& Yang, CC 2001, ‘On expressive voting: Evidence from the 1988 U.S. presidential election', Public Choice, vol. 108, no. 3, pp. 295-312.

Kwakofi, E 2016a, 'Mahama Pardons Montie 3', Ghana Newws, viewed 5 January 2017, <http:/ / citifmonline.com/2016/08/22/mahama-pardons-montie-3/>.

Kwakofi, E 2016, 'NPP Floors NDC to Claim Majority in Parliament' 12 December, retrieved from http://citifmonline.com/2016/12/12/npp-floors-ndc-toclaim-majority-in-parliament/

Kwakye, JK 2013, 'A Ghanaian Election' The Chronicle - Ghana News, viewed 4 January 2017, <http:// thechronicle.com.gh/a-ghanaian-election/>.

Kwakye, JK, 2014, 'Genesis and Solutions to Ghana's Current Economic Crisis', Graphic Online 13 May, retrieved 4 January 2017 from http:/ / www.graphic.com.gh/news / politics / genesis-and-solutions-to-ghana-s-current-economic-crisis.html

Lindberg, SI 2004, 'The Democratic Qualities of Competitive Elections: Participation, Competition and Legitimacy in Africa', Commonwealth $\mathcal{E}$ Comparative Politics, vol. 42, no. 1, p. 61.

Lindberg, SI 2006, Democracy and Elections in Africa, Johns Hopkins University Press, Baltimore.

Lindberg, SI \& Morrison, MKC 2005, 'Exploring Voter Alignments in Africa: core and swing voters in Ghana', The Journal of Modern African Studies, vol. 43 no. 4, p. 565, https: / / doi.org/10.1017/S0022278X05001229

- 2008, 'Are African Voters Really Ethnic or Clientelistic? Survey Evidence From Ghana', Political Science Quarterly, vol. 123, no. 1, pp. 95-122.

Myjoyonline.com 2016, ‘I Will Restore Your Allowances In Full - Akufo-Addo Promises Nurses, Teacher Trainees' September 21, retrieved 4 January 2017, from http:/ / www.myjoyonline.com/politics/2016/September-21st/iwill-restore-your-allowances-in-full-akufo-addo-promises-nurses-teachertrainees.php 
National Democratic Congress (Ghana) 2016, NDC's 2016 Manifesto, retrieved 4 January 2017, from http://johnmahama.org/wp-content/ uploads / 2016/05/2016-Manifesto.pdf

New Patriotic Party (Ghana) 2016, Manifesto, retrieved 4 January 2017, from http: / / newpatrioticparty.org/ docs / 2016-manifesto-full.pdf

Obempong, A 2016, Mahama's Excessive Use of State Resources for Campaign Condemned, viewed 5 January 2017, <http://www.thestatesmanonline. $\mathrm{com} /$ index.php / politics/2702-mahama-s-excessive-use-of-state-resources-for-campaign-condemned $>$.

Osei, A 2013, 'Party System Institutionalization in Ghana and Senegal', Journal of Asian and African Studies, vol. 48, no. 5, pp. 577-593.

Smith, DA 2002, 'Ghana's 2000 Elections: Consolidating Multi-party Democracy', Electoral Studies, vol. 21, no. 3, pp. 519-526.

The Economist 2016, 'Nkrumah's Heirs' November 19, retrieved 4 January 2017, from http:/ / www.economist.com/ news / middle-east-and-africa/21710286country-should-be-beacon-african-democracy-ailing-nkrumahs-heirs

Tornyi, E 2015, ' Fighting Corruption: Nana Addo to Form Independent Prosecutor to Fight Corruption July 19', retrieved 4 January 2017, from http:/ / pulse. com.gh / politics / fighting-corruption-nana-addo-to-form-independentprosecutor-to-fight-corruption-id3988802.html

TradingEconomics 2016,' Ghanaian Cedi: 2007-2017', viewed 4 January 2017, <http:/ / www.tradingeconomics.com/ghana/currency>.

Wain, B 2009, Malaysian Maverick - Mahathir Mohamad in Turbulent Times, Palgrave Macmillan, UK, viewed 5 January 2017, <http:/ / www.palgrave.com/us/ book/9780230367869>.

Whitfield, L 2003, 'Civil Society as Idea and Civil Society as Process: The Case of Ghana', Oxford Development Studies, vol. 31, no. 3, pp. 379-400.

Whitfield, L 2009, "“Change for a Better Ghana": Party Competition, Institutionalization and Alternation in Ghana's 2008 Elections', African Affairs, vol. 108, no. 433, pp. 621-641.

Wiafe, G 2016, ' IMF Warns of Full-Blown Financial, Economic Crises in Ghana if...' 5 October, MyJoyOnline, retrieved 4 January 2017, from http:/ / www. myjoyonline.com/business / 2016/October-5th/imf-warns-of-full-blownfinancial-economic-crises-in-ghana-if.php

Yobo, E \& Gyampo, R 2015, 'Third Parties and Electoral Politics in Ghana's Fourth Republic', Journal of Politics and Law, vol. 8, no. 2, pp. 7-16. 